\title{
Pengaruh Jenis Sulur dan Jumlah Ruas terhadap Pertumbuhan Sirih Buah Asal Desa Tunmat Kecamatan Io Kufeu Kabupaten Malaka (Piper betle, L)
}

\author{
Sesilia Niis Tae ${ }^{\mathrm{a}}$, Syprianus Ceunfin ${ }^{\mathrm{b}}$, dan Maria Afnita Lelang ${ }^{\mathrm{c}}$ \\ ${ }^{a}$ Fakultas Pertanian, Universitas Timor, Kefamenanu, TTU - NTT, Indonesia. \\ ${ }^{\mathrm{b}}$ Fakultas Pertanian, Universitas Timor, Kefamenanu, TTU - NTT, Indonesia. \\ ${ }^{\mathrm{c}}$ Fakultas Pertanian, Universitas Timor, Kefamenanu, TTU - NTT, Indonesia.
}

\section{Article Info}

Article history:

Received 4 Mei 2017

Received in revised form 17 Juni 2017

Accepted 5 Juli 2017

Keywords:

Sulur

Sirih

Stek

\begin{abstract}
Abstrak
Penelitian bertujuan untuk mengetahui pengaruh jenis sulur dan jumlah ruas terhadap pertumbuhan sirih buah asal desa Tunmat, kecamatan Io Kufeu, kabupaten Malaka. Penelitian menggunakan Rancangan Acak Lengkap dengan percobaan faktorial. Faktor pertama adalah jenis sulur, yang terdiri dari sulur panjat dan sulur tanah. Faktor kedua adalah jumlah ruas yaitu 3 ruas, 5 ruas, dan 7 ruas yang diulang sebanyak 6 kali. Hasil penelitian menunjukkan bahwa Terjadi interaksi antara perlakuan jenis sulur dan jumlah ruas pada parameter pengamatan jumlah tunas cabang 90 HST, dan jumlah daun 90 HST. Jenis sulur tanah yang dikombinasikan dengan jumlah ruas 7 menghasilkan jumlah tunas cabang, tinggi tanaman, diameter batang dan jumlah daun paling tinggi. Jenis sulur panjat yang dikombinasikan dengan jumlah ruas 5 tidak terjadi interaksi namun memberikan hasil tanaman sirih buah tertinggi pada parameter luas daun, berat segar daun dan berat segar total. @2017 dipublikasikan oleh Savana Cendana.
\end{abstract}

\section{Pendahuluan}

Sirih buah (Piper betle, L.) merupakan tanaman yang merambat dan memanjat pada batang pohon lain yang telah banyak dikenal oleh masyaraka karena manfaat sirih buah yang sering digunakan dalam hidangan acara ada serta menjamu tamu (mариа) dalam masyarakat Timor. Sirih buah banyak digemari oleh banyak lapisan masyarakat baik kaum laki-laki maupun perempuan di Kabupaten Malaka dan Timor pada umumnya sebagai bahan campuran dengan pinang dan kapur yang dimakan (mamatatau mamta). Dilihat dari sisi ekonomi tanaman sirih sangat memberikan keuntungan bagi petani yang membudidayakannya karena dapat dijual untuk memenuhi kebutuhan hidupnya.

Daun sirih mengandung minyak atsiri (Betlephenol dan Seskuiterpen) pati, diastase, gula, zat semak dan chavicol yang memiliki daya mematikan kuman, antioksidan serta fungisida. Manfaat lain sirih adalah dapat menghilangkan baubau yang ditimbulkan bakteri dan cendawan (Agoes, 2010). Daun sirih juga menahan pendarahan, menyembuhkan luka pada kulit, dan gangguan saluran pencernaan. Selain itu sirih juga dapat menyembuhkan penyakit keputihan, sakit gigi, demam berdarah, bauh mulut, haid yang tidak teratur, asma, radang tenggorokan (daun dan minyaknya), gusi bengkak (getah), eksin, luka bakar, pendarah gusi dan menghilangkan gatal-gatal (Thomas, 1985). Tanaman sirih memiliki daun yang melekat disetiap ruas dan setiap satuan ruas terdiri atas satu ruas, yang membawa sebuah daun dan satu ruas. Laju produksi ruas pada setiap tunas menurun dan kira-kira satu ruas setiap hari selama awal pertumbuhannya sampai kira-kira satu ruas perminggu pada tanaman berumur satu tahun (Tan $e$ $a l$,. 1980). Tanaman sirih dalam pertanian dimanfaatkan sebagai fungsida, yakni membasmi hama pengganggu dan perusak tanaman, pemakain sirih untuk mengendalikan jamur phythophithora palmivora penyebab busuk pangkal batang yang menyerang tanaman lada (Darmawaty, 2003).

Tanaman ini mempunyai manfaat penting bagi masyarakat, namun cara pembudidayaannya masih menggunakan teknologi tradisional yang dilakukan turun menurun. Cara tradisional yang diterapkan adalah stek yang telah diambil dari pohon induk, pada pangkal dililit membentuk lingkaran, kemudian langsung ditancapkan pada lubang tanam yang telah diisi dengan serasah dekat tiang panjat serta ditutupi dengan sisa tanah yang di sekitar lubang tanam (Asiamaya, 2007). Dengan cara ini bibit yang diperoleh jumlahnya terbatas dan resiko kematian sangat tinggi. Oleh karena itu perlu teknologi sederhana untuk perbanyakan tanaman tersebut.

Laju produksi ruas antara varietas terdapat perbedaan, walaupun demikian pada klon yang tidak bercabang. Penurunan laju produksi daun karena umur pada setiap ujungnya, adalah kurang nyata dibandingkan dengan klon-klon lain (Tan dan Cock, 1979b). Suhu yang lebih rendah menurunkan laju produksi daun baru (Irikura et al., 1979; Keating 1981) dan periode kering yang panjang hampir sepenuhnya menekan produksinya (Connor dan Cock, 1981). Setiap ruas terus meningkat beratnya selama pertumbuhan tetapi laju peningkatannya kurang pada periode kering atau bila zat hara terbatas.

Jumlah ruas total tiap tanaman bergantung pada jumlah ruas setiap tunas dan jumlah tunas atau pucuk setiap tanaman. Sedikit ketahui tentang pengaturan percabangan atau percabangan garpu (forking). Beberapa klon akan bercabang awal dan terus bercabang sedang yang lain tidak pernah diketahui bercabang. Pada kondisi lingkungan yang konstan tenggang waktu pembentukan setiap cabang yang berurutan cenderung konstan apabila jumlah cabang setiap tempat percabangan (garpu) sedikit tetapi meningkat bila jumlah cabang banyak (Tan dan Cock 1979; CIAT, 1979). Lebih sedikit percabangan garpu dihasilkan pada tanah yang kurang subur khususnya untuk tipe tanaman yang secara normal bercabang banyak (CIAT, 1979). Jarak antara percabangan garpu juga meningkat oleh cekaman air selama siklus pertumbuhannya (Connor dan Cock 1981). Penelitian ini bertujuan untuk mengetahui pengaruh jenis sulur dan jumlah ruas terhadap pertumbuhan sirih buah asal desa Tunmat, kecamatan Io Kufeu, kabupaten Malaka.

\section{Metode}

Penelitian dilaksanakan pada bulan Agustus sampai November 2016 di kebun percobaan Fakultas Pertanian, Universitas Timor Kelurahan Sasi, Kecamatan Kota Kefamenanu, Kabupaten TTU. Rancangan penelitian yang digunakan adalah Rancangan Acak Lengkap (RAL) dengan percobaan faktorial yang menggunakan 2 (dua) faktor. Faktor pertama adalah jenis sulur (S) yang terdiri dari sulur panjat $\left(\mathrm{s}_{1}\right)$, sulur tanah $\left(\mathrm{s}_{2}\right)$. Faktor kedua adalah jumlah ruas (R) yaitu $\left(r_{1}\right) 3$ ruas, $\left(r_{2}\right) 5$ ruas, $\left(r_{3}\right) 7$ ruas, dengan kombinasi perlakuannya $s_{1} r_{1}$ $\mathrm{s}_{1} \mathrm{r}_{2}, \mathrm{~s}_{1} \mathrm{r}_{3} \mathrm{~s}_{2} \mathrm{r}_{1}, \mathrm{~s}_{2} \mathrm{r}_{2}, \mathrm{~s}_{2} \mathrm{r}_{3}$ yang diulang sebanyak 6 kali sehingga terdapat 36 kombinasi perlakuan.

Lokasi penanaman berbentuk persemaian, lahan dibersihkan dari gulma dan dibuatkan naungan menggunakan daun kelapa dengan tinggi $\pm 2 \mathrm{~m}$, untuk mengurangi sinar matahari secara langsung dengan menggunakan daun kelapa. Media tanam yang digunakan adalah tanah, pasir dan pupuk kandang dengan perbandingan 2:1:1. Ketiga jenis media tersebut dicampur merata kemudian dimasukan dalam polybag berdiameter $35 \times 35 \mathrm{~cm}$. Polybag tersebut kemudian disusun membentuk blok, setiap blok berisi 6 unit polybag sesuai dengan perlakuan.

Bahan tanaman yang digunakan dalam penelitian ini berasal dari pohon induk yang terletak di Desa Tunmat Kecamatan Io Kufeu yang telah berusia \pm 5 tahun. Bahan tanaman yang diambil sesuai dengan perlakuan yaitu dari sulur panjat dan sulur tanah dengan jumlah ruas sesuai perlakuan dan jumlahnya disesuaikan dengan perlakuan. Bahan stek yang digunakan adalah cabang sekunder dari tanaman induk. Penanaman dilakukan dengan cara menancapkan pangkal stek ke dalam media tanaman sedalam $1 / 2$ dari panjang stek sebelum ditanam pangkal stek diikat dan direndam di dalam air bersih. Perendaman dilakukan selama 4 jam untuk menjaga kesegaran bahan tanaman. Setiap polybag ditanami satu bahan tanaman sesuai perlakuan. Setiap kombinasi perlakuan dicadangkan sebanyak 3 unit sehingga total unit percobaan adalah 66 unit.

Pemberian air pada tanaman dilakukan dengan cara disiram menggunakan gembor yang dilakukan sebelum stek ditanam agar tanah di dalam polybag tetap lembab. Penyiraman dilakukan dua kali sehari yakni pagi dan sore atau sesuai kondisi media tanam. Parameter pengamatan meliputi jumlah tunas cabang, jumlah daun, luas daun, berat segar daun tanaman, berat segar total tanaman. Jumlah tunas yang dihitung adalah semua tunas yang tumbuh pada tanaman dalam polybag serta tunas yang keluar dari ketiak-ketiak daun. Jumlah tunas dihitung 3 kali selama penelitian yaitu pada saat tanaman berumur 30 har setelah tanam (HST), 60 HST, 90 HST. Jumlah tunas yang dihitung adalah jumlah tunas yang telah menghasilkan minimal 1 daun penuh.

Jumlah daun dihitung dari semua daun yang tumbuh pada setiap unit perlakuan. Jumlah daun dihitung 3 kali selama penelitian yaitu $30 \mathrm{HST}$, 60 HST, 90 HST dan yang dihitung adalah daun yang telah terbuka penuh dan masih berwarna hijau. Luas daun tanaman sirih diukur dengan cara daun dipanen kemudian dipisahkan dari batang lalu daun tersebut di hitung menggunakan metode fotometri yaitu dengan cara daun discan kemudian dihitung menggunakan ImageJ. Luas permukaan daun dihitung pada saat panen atau pada akhir penelitian.

Berat segar daun diukur dengan menimbang bagian daun tanaman yang telah dipisahkan dari batang dan akar tanaman sebelum ditimbang. Penimbangan berat segar daundilakukan pada 2 ulangan dari setiap perlakuan yaitu pada ulangan 4 dan 5 kemudian dirata-ratakan untuk memperoleh berat segar daun tanaman. Penimbangan berat segar total tanaman dilakukan pada 2 ulangan dari setiap perlakuan yaitu pada ulangan 4 dan 5 kemudian dirataratakan untuk memperoleh berat segar daun tanaman. Penimbangan dilakukan setelah tanaman dicuci besih dan setelah air ditiriskan

Hasil pengamatan dianalisis dengan menggunakan analisis sidik ragam menggunakan Rancangan Acak Lengkap (RAL) faktorial untuk mengetahui ada tidaknya interaksi antara faktor perlakuan. Rata-rata perlakuan selanjutnya 
diuji dengan Duncan Multiple Range Test (DMRT) dengan tingkat signifikan 5\% sesuai petunjuk Gomez dan Gomez (2010), menggunakan software SAS 9.1.

\section{Hasil dan Pembahasan}

\subsection{Jumlah Tunas Cabang}

Analisis statistik data hasil pengamatan terhadap jumlah tunas cabang tanaman sirih menunjukkan tidak terjadi interaksi pada umur 30 HST, tetapi terjadi interaksi pada saat tanaman berumur 60 HST dan 90 HST. Gambar 1. menunjukkan bahwa pada pengamatan 90 HST terjadi interaksi dan berpengaruh nyata. Kombinasi sulur tanah dengan jumlah ruas 7 menghasilkan jumlah tunas paling banyak yang berbeda nyata dengan kombinasi perlakuan jenis sulur tanah dengan jumlah ruas 3 . Hal ini karena sulur tanah adalah sulur yang tumbuh di permukaan tanah. Sulur ini memiliki ruas yang relatif panjang, helaian daun lebih sempit dan tidak memiliki akar lekat (Tarioyono et al. 2004).

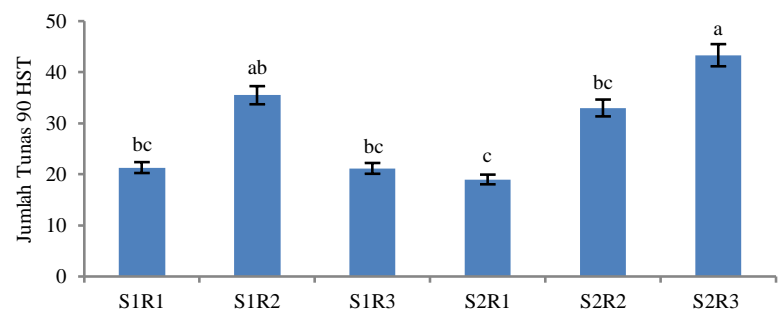

Gambar 1. Pengaruh jenis sulur dan jumlah ruas terhadap jumlah tunas; S1R1: Sulur panjat 3 Ruas, S1R2: Sulur panjat 5 Ruas, S1R3: Sulur panjat 7 Ruas, S2R1: Sulur tanah 3 ruas, S2R2: Sulur tanah 5 ruas, S2R3: Sulur tanah 7 ruas.

\subsection{Jumlah Daun}

Analisis statistik data hasil pengamatan terhadap pertumbuhan jumlah daun menunjukkan bahwa tidak terjadi interaksi pada waktu pengamatan 30 dan 60 HST sedangkan pada umur 90 HST terjadi interaksi.

Dari Gambar 2. menunjukkan bahwa pada pengamatan 90 HST jumlah daun paling banyak dihasilkan oleh kombinasi perlakuan sulur tanah dengan jumlah ruas 7 yang berbeda nyata dengan kombinasi perlakuan sulur tanah dengan jumlah ruas 3 . Hal ini karena salah satu bagian sink yang kompetitif pada masa pertumbuhan vegetatif adalah daun muda (tunas) yang sedang tumbuh (Gardner et al., 1991; Salisbury dan Ross, 1995). Semakin banyak tunas yang memperoleh hara maka pertumbuhan dan perkembangan tunastunas akan semakin cepat diikuti dengan meningkatnya jumlah daun.

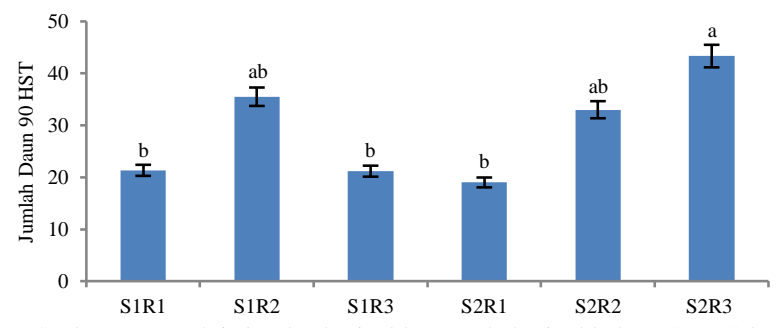

Gambar 2. Pengaruh jenis sulur dan jumlah ruas terhadap jumlah daun; S1R1: Sulur panjat 3 Ruas, S1R2: Sulur panjat 5 ruas, S1R3: Sulur panjat 7 ruas, S2R1: Sulur tanah 3 ruas, S2R2: Sulur tanah 5 ruas, S2R3: Sulur tanah7 ruas.

\subsection{Luas Daun}

Analisis statistik menunjukkan bahwa tidak terjadi interaksi terhadap parameter luas daun seperti terlihat pada Gambar 3. Hasil uji lanjut menunjukkan bahwa sulur panjat memberikan luas daun paling lebar dan berbeda nyata dengan sulur tanah, sedangkan jumlah ruas tidak berbeda nyata antar aras perlakuan

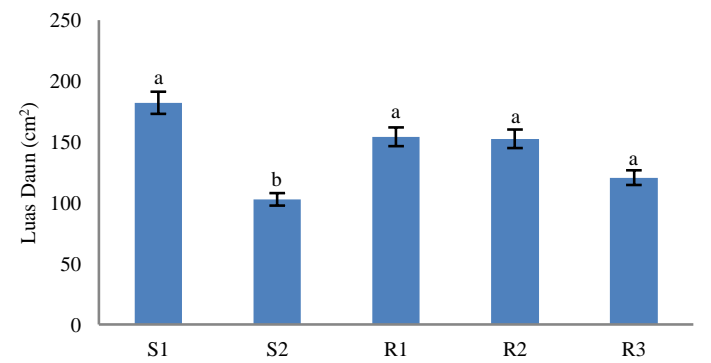

Gambar 3. Pengaruh jenis sulur dan jumlah ruas terhadap luas daun; S1: Sulur panjat, S2: Sulur tanah, R1: 3 ruas, R2: panjat 5 ruas, R3: panjat 7 ruas.

\subsection{Berat Segar Daun Tanaman}

Analisis statistik menunjukkan bahwa tidak terjadi interaksi terhadap parameter berat segar daun seperti terlihat pada Gambar 4. Berat segar daun dari sulur panjat lebih berat tetapi tidak berbeda nyata dengan jenis sulur tanah. Jumlah ruas 5 lebih berat dari jumlah ruas lainnya namun tidak berbeda nyata.

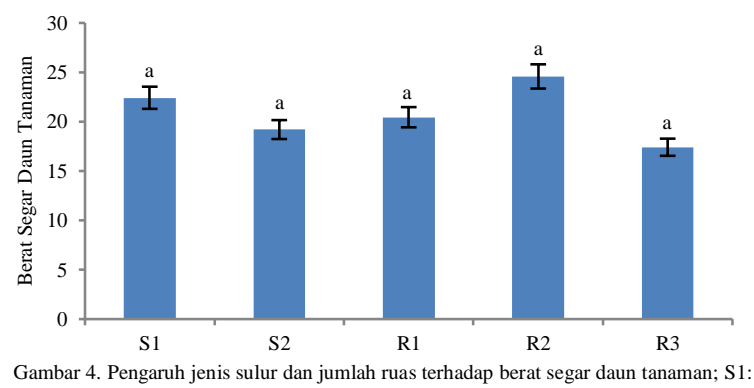

sulur panjat, S2: sulur tanah, $\mathrm{R} 1: 3$ ruas, $\mathrm{R} 2: 5$ ruas, $\mathrm{R} 3: 7$ ruas.

\subsection{Berat Segar Total}

Analisis statistik Sidik Ragam (anova) menunjukkan tidak terjadi interaksi terhadap parameter pengamatan berat segar total sirih buah seperti pada Gambar 5. Hasil uji lanjut menunjukkan tidak terjadi beda nyata antar aras perlakuan. Perlakuan bagian sulur panjat memberikan berat segar total paling berat dibandingkan dengan perlakuan sulur tanah.

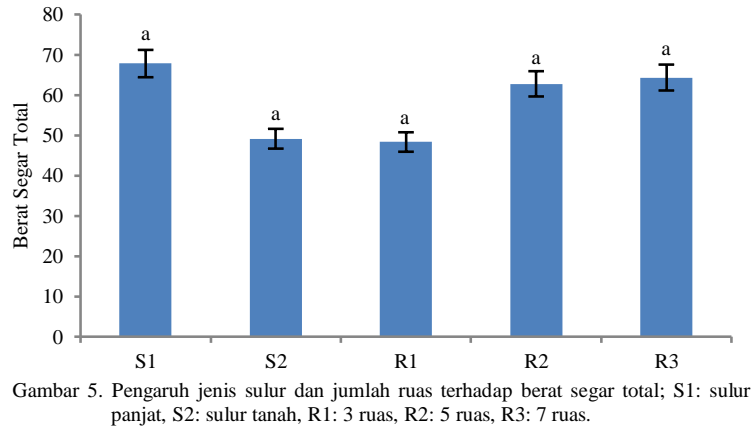

Pemberian perlakuan dengan bagian 7 ruas menghasilkan segar total terberat dibandingkan dengan perlakuan lainnya. Dari data tersebut tinggi tanaman, jumlah daun dan diameter batang, panjang akar berpengaruh pada berat segar berangkasan tanaman. Semakin besar tinggi tanaman, jumlah daun dan diameter batang, dan panjang akar maka berat segar akan meningkat. Hal ini disebabkan karena dalam pembiakan vegetatif sirih buah, sulur tanah dan panjat merupakan bahan stek yang dapat ditumbuhkan menjadi tanaman sirih yang baru (Hamid, 1972). Lebih lanjut Susilawati (2007) menjelaskan bahwa nitrogen dibutuhkan oleh tanaman dalam jumlah yang banyak karena nitrogen mempunyai fungsi merangsang pertumbuhan atau memperbaiki pertumbuhan vegetatif tanaman dan membantu pembentukan klorofil sehingga memberikan warna hijau kegelapan pada tanaman.

\section{Simpulan}

Terjadi interaksi antara perlakuan jenis sulur dan jumlah ruas pada parameter pengamatan jumlah tunas cabang 90 HST, dan jumlah daun 90 HST. Jenis sulur tanah yang dikombinasikan dengan jumlah ruas 7 menghasilkan jumlah tunas cabang, tinggi tanaman, diameter batang dan jumlah daun paling tinggi. Jenis sulur panjat yang dikombinasikan dengan jumlah ruas 5 tidak terjadi interaksi namun memberikan hasil tanaman sirih buah tertinggi pada parameter luas daun, berat segar daun dan berat segar total.

\section{Pustaka}

Agoes, A. 2010. Tanaman Obat Indonesia. Jakarta: Salemba Medika.

Asiamaya. 2007. Sirih (Piper. Betle L.) online. Bahan Mengajar Fisiologi Tumbuhan.

CIAT. 1979. Cassava Program. Annual Report 1978. Cali, Colombia: Centro International de Agricultura Tropical. AA67-13.

Connor, D.J dan J.H. Cock. 1981. The Response of Cassava to Water Shortage. II. Canopydinamics. Field Crops Res., 4: 285-296.

Darmayati. 2003. Khasiat dan manfaat Daun, Obat Mujarab dari Masa ke Masa. Jakarta: Gramedi pustaka.

Gardner, F.P., R.B. Pearce dan R. L. Mitchell. 1991. Fisiologi Tanaman Budidaya. Terjemahan: Herawati Susilo. Jakarta: UI Press.

Gomez, K. A. dan A. A. Gomes. 1995. Prosedur Statistik untuk Penelitian Pertanian. Edisi ke 2. Jakarta:UI Press.

Hamid, A.K. 1972. Taniaga Pertanian. IPB. Bogor.

Irikura, Y., J.H. Cock dan K. Kawano. 1979. The Physiological Basis of Genotype Temperatur Interactions in Cassava. Field Crops Res. 2: 227-239.

Keating, B.A dan J.P. Evenson.1979. Effect of Soil Temperature on Sprouting and Sprout Elengation of Stem Cuttings of Cassava. Field Crops Res. 2: 241-252.

Keating, B.A. 1981. Environmental Effectson Growth and Development of Cassava (Manihot esculenta Crantz) with Special Reference to Photoperiod and Temperatur. PhD Thesis. Dept. of Agric. Univ. of Qeenland. Autralia. 
Salisbury FB dan Ross CW.1995. Fisiologi Tumbuhan Jilid 3. Perkembangan

Tumbuhan dan Fisiologi Lingkungan. Terjemahan dari Plant Physiology. $4^{\text {th }}$ ed. oleh Lukman DR \& Sumaryono. Bandung: Penerbit ITB. Susilawati,E. 2007. Pengaruh komposisi Media terhadap Perkecambahan dan Pertumbuhan Tanaman Helichrysum Bracleatum dan Zinnia Elegans. [Makalah Seminar]. Agronomi dan Hortikultura Fakultas Pertanian, IPB. Bogor.

Taryono dan Agus Ruhhayat. 2004. Cabe Jawa. Jakarta: Penebar Swadaya.

Tan, S.L. 1980. Growth Parametrs Related Toproductivity in Cassava. Masters of Agric. Sci. Thesis. Universiti Pertanian. Malaysia.

Tan, S.L. dan J.H. Cock. 1979a. Branching Habit as a Yield Diterminant in Cassava. Field Crops Res. 2: 281-289.

Tan, S.L. dan J.H. Cock. 1979b. Cassava Plant froms and Their Associated Morphophysiological Charaters. MARDI. Res. Bull. 7: 55-69.

Thomas A.N.S. 1985. Tanaman Obat Tradisional. Yogyakarta: Kanisius. 